\title{
Assessment of health/functioning of older adults who consume psychoactive substances
}

\author{
Avaliação da saúde/funcionalidade de pessoas idosas consumidoras de substâncias psicoativas
}

Evaluación de la salud/funcionalidad de personas ancianas consumidoras de sustancias psicoactivas

\author{
Vania Dias Cruz', Silvana Sidney Costa Santos', Jamila Geri Tomaschewski-Barlem', \\ Bárbara Tarouco da Silva', Celmira Lange", Daiane Porto Gautério de Abreu', Flávia Seles Oliveira' \\ ' Federal University of Rio Grande do Sul, School of Nursing. Rio Grande, Rio Grande do Sul, Brazil. \\ "Federal University of Pelotas. Pelotas, Rio Grande do Sul, Brazil.
}

How to cite this article:

Cruz VD, Santos SSC, Tomaschewski-Barlem JG, Silva BT, Lange C, Abreu DPG, et al. Assessment of health/functioning of older adults who consume psychoactive substances. Rev Bras Enferm [Internet]. 2018;71(3):942-50. DOI: http://dx.doi.org/10.1590/0034-7167-2016-0637

Submission: 03-27-2017 Approval: 05-13-2017

\begin{abstract}
Objective: To assess the health/functioning of the older adult who consumes psychoactive substances through the International Classification of Functioning, Disability and Health, considering the theory of complexity. Method: Qualitative case study, with 11 older adults, held between December 2015 and February 2016 in the state of Rio Grande do Sul, using interviews, documents and non-systematic observation. It was approved by the ethics committee. The analysis followed the propositions of the case study, using the complexity of Morin as theoretical basis. Results: We identified older adults who consider themselves healthy and show alterations - the alterations can be exacerbated by the use of psychoactive substances - of health/functioning expected according to the natural course of aging such as: systemic arterial hypertension; depressive symptoms; dizziness; tinnitus; harmed sleep/rest; and inadequate food and water consumption. Final consideration: The assessment of health/functioning of older adults who use psychoactive substances, guided by complex thinking, exceeds the accuracy limits to risk the understanding of the phenomena in its complexity.

Descriptors: Older Adult; Drug Users; International Classification of Functioning, Disability and Health; Geriatric Nursing; Nursing Care.
\end{abstract}

\section{RESUMO}

Objetivo: Avaliar a saúde/funcionalidade da pessoa idosa que consome substâncias psicoativas a partir da Classificação Internacional de Funcionalidade, Incapacidade e Saúde, sob o olhar da complexidade. Método: Estudo de caso qualitativo, com 11 idosos, realizado entre dezembro de 2015 a fevereiro de 2016, no Rio Grande do Sul, utilizando-se entrevista, documentos e observação assistemática. Teve aprovação do comitê de ética. A análise seguiu as proposições do estudo de caso, tendo como eixo teórico a complexidade de Morin. Resultados: Identificaram-se pessoas idosas que se consideram saudáveis e que apresentam alterações - as quais podem ser exacerbadas pelo uso de substâncias psicoativas - de saúde/funcionalidade esperadas com o percurso natural do envelhecimento, como: hipertensão arterial sistêmica; sintomas depressivos; tontura; zumbido; sono/repouso prejudicado; alimentação e ingesta hídrica inadequada. Considerações finais: A avaliação da saúde/ funcionalidade de pessoas idosas que consomem substâncias psicoativas, guiada pelo pensamento complexo, ultrapassa os limites da precisão para arriscar compreender os fenômenos em sua complexidade.

Descritores: Idoso; Usuários de Drogas; Classificação Internacional de Funcionalidade, Incapacidade e Saúde; Enfermagem Geriátrica; Cuidados de Enfermagem.

\section{RESUMEN}

Objetivo: Evaluar la salud/funcionalidad de la persona anciana que consume sustancias psicoactivas desde de la Clasificación Internacional de Funcionalidad, Incapacidad y Salud, bajo la mirada de la complejidad. Método: Estudio de caso cualitativo, con 11 ancianos, realizado entre diciembre de 2015 y febrero de 2016, en Rio Grande do Sul, utilizándose encuesta, documentos y 
observación asistemática. Tuvola aprobación del comité de ética. El análisis siguió las proposiciones del estudio de caso, teniendo como el eje teórico la complejidad de Morín. Resultados: Se identificaron a personas ancianas que se consideran saludables y que presentan alteraciones - Las cuales pueden ser agravadas por el uso de sustancias psicoactivas — de salud/funcionalidad esperadas con el recurrido natural del envejecimiento, como: la hipertensión arterial sistémica; los síntomas depresivos; el mareo; el zumbido; el sueño/reposo perjudicado; la alimentación y la ingesta hídrica inadecuada. Consideraciones finales: La evaluación de la salud/funcionalidad de personas ancianas que consumen sustancias psicoactivas, guiada por el pensamiento complejo, sobrepasa los límites de la precisión para arriesgar comprender los fenómenos en su complejidad.

Descriptores: Anciano; Usuarios de Drogas; Clasificación Internacional de Funcionalidad, Incapacidad y Salud; Enfermería Geriátrica; Atención de Enfermería.

\section{CORRESPONDING AUTHOR Vania Dias Cruz E-mail: vania_diascruz@hotmail.com}

\section{INTRODUCTION}

Research on the consumption of Psychoactive Substances (PAS) among older adults focus primarily on the use of medications and disorders related to the consumption of alcoholic beverages. Studies regarding the use of illicit substances in European countries, especially in the United Kingdom, are punctual and systematic and consider ages above 50 years, also including older adults, i.e., those aged 60 years and over $^{(1)}$. In Brazil, and especially in the nursing area, they are not common. A study conducted in the state of São Paulo, in a Centro de Atenção Psicossocial Álcool e Outras Drogas [Psychosocial Care Center - Alcohol and Other Drugs (from the Portuguese, CAPS - AD)], identified that the PAS most used by older adults is alcohol, followed by marijuana and crack or cocaine, the use of tobacco is not considered ${ }^{(2)}$.

The places and behaviors that were formerly assigned to older adults, such as taking care of the grandchildren and having their lives led by their children/family, are no longer the norm. Dating, using PAS and going to parties are behaviors that can be part of the daily life of the older adults, this requires that society rethinks and "rewatches" this new form of aging and the abandonment of traditional patterns ${ }^{(3)}$.

When reflecting on people who consume PAS it is necessary not to judge, but to understand that this is a circular process, i.e., it goes from separating to uniting, from uniting to separating; additionally, from the analysis to the synthesis and from the synthesis to analysis, thus allowing the deconstruction, the uncertainty and the reconstruction, key elements for understanding the complexity ${ }^{(4)}$.

From this perspective, it is important that the health care professional/nurse understands that the substance is not the exclusive responsible for the worsening of the health problems of the older adult, since external factors, such as poverty, family structure, cultural context and the aging process itself, can be as influential as the substance use. A complex look, according to the theory of complexity of Edgar Morin, is required to be able to have this type of view.

Complexity is a problem and not an answer and means what was woven together. There is an interdependent fabric between the object of your knowledge and its context. It is the union between unity and multiplicity ${ }^{(4)}$. Complexity is, effectively, the fabric of events, actions, interactions, feedback, determinations, accidents, which constitute the context of the older adult who consumes PAS; a wider outlook and actions directed to the non-fragmentation, order/disorder of this multidimensional system are necessary.

Understanding the phenomenon of the use of PAS from a single trend is unlikely, i.e., the consequences of consumption are related to the psychological factor of the consumer and to its sociocultural context ${ }^{(5)}$. Understanding the environment in which the older adult lives or transits becomes necessary, as well the focus on the characteristics of its daily life and social support networks, in addition to the pharmacological properties of the consumed substance. For this reason, using the International Classification of Functioning, Disability and Health (ICF) is important.

Using elements of the ICF could understand the older adult who consumes PAS in its entirety, analyzing/articulating the relations between the whole and the parts. ICF is a classification of the World Health Organization (WHO), which proposes a model to approach human functionality. Its goal is to provide an unified and standardized terminology language as well as the framework to describe the health and healthrelated conditions ${ }^{(6)}$.

ICF is divided into two parts: functioning/disability and contextual factors. The first is described in domains based on the perspective of the body, the individual and society, being presented in two basic lists: functions and structures of the body; and activities and participation. The second includes the environmental and personal factors ${ }^{(6)}$. Identifying the functioning/disability related to health conditions is possible through ICF, this allows the diagnosis of the ability of the older adult to perform daily life activities, focusing on the functions of the organs, body structures and the participation in the social environment where the person lives.

The use of PAS among older adults can be considered a complex/multifactorial situation, marked by invisibility since the indexes of consumption of this population are underestimated and poorly identified ${ }^{(2)}$, which justifies the production of this study. Through the use of the theoretical framework of Morin, capturing new perspectives regarding the age range of the older adults who consume PAS and assisting the nurse to understand the behaviors of these older adults is possible, this serves as a basis for changes in professional attitudes.

Thus, we question: How is the assessment of health/functioning of the older adult who consumes psychoactive substances through the International Classification of Functioning, Disability and Health, considering the theory of complexity? 


\section{OBJECTIVE}

To assess the health/functioning of the older adult who consumes psychoactive substances through the International Classification of Functioning, Disability and Health, considering the complexity theory.

This article understands the psychoactive substance user as the person who consumes legal or illegal psychotropic substances, with no medical or therapeutic intent.

\section{METHOD}

\section{Ethical aspects}

The ethical aspects of the Resolution no.466/2012, of the National Health Council - NHC were complied, being approved by the Research Ethics Committee.

\section{Methodological procedures}

\section{Type of study and Scenario}

Qualitative case study ${ }^{(7)}$ based on Morin's theory of complexity, using elements of the International Classification of Functioning, Disability and Health to assess the health/functioning of the older adult who consumes psychoactive substances.

The study was performed on 11 older adults who consume PAS. Inclusion criteria was: at least 60 years of age and users of PAS. It was developed in a city of the state of Rio Grande do Sul, Brazil, through the registry in the Harm Reduction Strategy with the help of Agentes Redutores de Danos [Harm Reduction Agents] or Agentes Comunitários de Saúde [Community Health Agents].

In the first moment a research was held in the registry of the Harm Reduction Strategy (HRS) service, located in the Municipal Secretariat of Health (from the Portuguese, Secretaria Municipal de Saúde - SMS), for PAS users over 60 years of age. Initially, the search of the records was limited to older adults who live in a neighborhood known for the large number of users and dealers of substances. However, access to these people was difficult because of the change of addresses, households not found, deaths and the limited number of older adults who use illicit substances registered in the HRS, new analyses were done without limiting the neighborhood.

Using this information, Harm Reduction Agents pointed to users who kept some bond/contact with the service, thus being easier to locate them. Data collection occurred in both the natural environment of the participant (households) and in the health services frequented by the older adult, Basic Health Unit (from the Portuguese, Unidade Básica de Saúde - UBS) or CAPS - AD, depending on the availability of the investigated older adult and of health professionals to monitor the researcher. Data collected at households always had the presence of Harm Reducing Agents or Community Health Agents.

The previous contact happened in the presence of health professionals, the users were met through home visits or in the Health Units of those who had appointments. The contact with the users was held at the time of the interview, and there were no denials to participate.

\section{Data collection and organization}

Data collection was done through: field journal (non-systematic description of the observations), the documents reviewed (with emphasis on the registers of older adults on the Harm Reduction Strategy and in the readings of the medical records of the patient/family) and through semi-structured and individual interviews ${ }^{(8)}$ held from December 2015 to February 2016.

At first, the documentary research allowed the understanding of the older adults and a greater amount of information regarding the consumption of PAS, these served as a source to confirm and detail the data obtained through the interview.

Semi-structured and individual interview was applied as a form, based on the ICF. To identify the set of categories of the ICF of greater importance to the older adults, members of the Grupo de Estudo e Pesquisa em Gerontogeriatria, Enfermagem / Saúde e Educação da Universidade Federal do Rio Grande [Study and Research Group in Gerontology, Geriatrics, Nursing/Health and Education of the Federal University of Rio Grande] developed an instrument based on the model of the Likert scale and on the ICF. The instrument consisted of 107 items (45 related to body functions, 38 related to the participation and activity, 24 related to the environment) and it was sent online to a group of 31 nurses with $\mathrm{PhD}$ in health care of older adults -13 nurses responded. After the evaluation of the experts, the elements that were manifested in $80 \%$ or more responses were identified as the set of categories essential to the assessment of health/ functioning of the older adults. This option was chosen by the group considering elements of descriptive statistics and absolute medians.

The instrument of data collection for this research was created using this information, a semi-structured interview that was recorded and subsequently transcribed in its entirety, preserving the authenticity of each statement.

Non-systematic observation techniques were used during the interview to identify behaviors, gestures and expressions that could complement the data seized in the interview. These were registered in a field journal to reduce the possibilities of loss of important information ${ }^{(7)}$.

The incorporation of data that composed the material for analysis was done through these three collection methods.

\section{Data analysis}

Three strategies were used for data analysis: 1) the general analytical strategy, which defined the priorities that were analyzed and justified, combining the collected data according to the ICF domains; 2) the analytic descriptive strategy, which constituted the description of the cases and their consequences, giving importance to the statements of the participants and the frequency of manifestation of the most relevant ICF elements, allowing the creation of charts / tables and the organization of themes/categories; 3 ) the theoretical analytical strategy, established the framework based on the literature review and on the Morin's theory of complexity, allowing reflections and new interpretations about the use of PAS by older adults ${ }^{(7)}$. 


\section{RESULTS}

The numerical data relating to health changes presented in this section (in Chart 1) were retrieved from the interview instrument based on the ICF, which presented itself as a valuable resource to identify the health conditions of these participants with the endorsement of the interviews.

The older adults investigated were two women and nine men; between 60 and 79 years; eight white, one of mixed-race and two black; four live alone and seven live with family; five are married or in common-law marriage, two are divorced, two are widows and two are single; all of them have children; five are retired, one is a pensioner and five are self-employed; nine have monthly income up to one minimum wage and two older adults have income of two minimum wage salaries; nine reside in own house and two in loaned residences, all of masonry.

Regarding satisfaction with health and life, two reported dissatisfaction and nine reported satisfaction. The dissatisfied older adults report unhappiness with the lifestyle they currently have:

Today I feel like a person who is disrupting the life of another (person) who is good. I would like to stop, but it is hard. (CASE 1)

The older adults satisfied with their health/life claim that they are conformed despite having diseases, since they have what is necessary to survive.

Considering everything I went through, my life is very good. I starved, I was homeless and depended on other people. Thanks to God, today I have a home. (CASE 3)
Thank God, I can't complain about anything, I have these heart and blood pressure conditions, but otherwise I have a family that always cared for me. (CASE 4)

Regarding satisfaction with health, according to the assessment of health/functioning of the ICF, the older adults show no signs/symptoms that are harmful to their daily life. They exercise and tolerate well the activities; they apply their knowledge, make decisions and perform activities of their daily lives; they present good communication skills; they walk over short and long distances; they take care of their own health, socialize and report little climate/temperature interference in daily routine.

The older adults of the research primarily use tobacco, alcohol, marijuana and/or cocaine. The main alterations identified were: Systemic Arterial Hypertension ( $\mathrm{SAH}$ ) and signs of depression; alteration in perception, such as visual and auditory hallucinations. Ten reported decreased visual acuity; sometimes dizziness and tinnitus relating to alteration in arterial pressure (AP) and glucose; some have reported difficulties in maintaining/onset of sleep/waking up several times during the night. The older adults drink less than two liters of water per day and have an inadequate diet, with no fruits or vegetables. Nine of the older adults reported the presence of pain, especially althralgia and lumbalgia. Tingling on the body was also mentioned. Difficulties to deal with psychological crisis and moments of stress, and fragile support ties with neighbors and professionals from the Basic Health Units of the neighborhood are part of the life of the older adults.

The main alteration related to health/functioning of the older adults users of PAS are illustrated in the following table.

Chart 1 - Comparative chart between the investigated older adults regarding the evaluation of health/functioning based on the Classification of Functioning/Health, Rio Grande do Sul, Brazil, 2015/2016 (N=11)

\begin{tabular}{|c|c|c|c|c|c|c|c|c|c|c|c|}
\hline Health/functioning systems & \multicolumn{11}{|c|}{$\begin{array}{l}\text { Alterations in health and functioning } \\
\text { Cases/Older adults with alterations }\end{array}$} \\
\hline \multirow{2}{*}{ Disease history } & \multicolumn{2}{|c|}{$\begin{array}{l}\text { Depressive } \\
\text { symptoms }\end{array}$} & \multicolumn{2}{|c|}{$\mathrm{SAH}^{1}$} & \multicolumn{2}{|c|}{ Cardiopathy } & $\mathrm{DM}^{2}$ & $\begin{array}{l}\text { Psychiatric } \\
\text { illness }\end{array}$ & \multicolumn{2}{|c|}{$\begin{array}{l}\text { Peptic } \\
\text { ulcer }\end{array}$} & $\mathrm{HIV}^{3}$ \\
\hline & \multicolumn{2}{|c|}{$1,2,6,10,11$} & \multicolumn{2}{|c|}{$1,3,4,6,11$} & \multicolumn{2}{|c|}{1,4} & 3,6 & 7 & \multicolumn{2}{|c|}{8} & 11 \\
\hline \multirow{3}{*}{$\begin{array}{l}\text { Psychoactive substances } \\
\text { Used }\end{array}$} & \multicolumn{3}{|c|}{ Tobacco } & \multicolumn{2}{|c|}{ Alcohol } & \multicolumn{2}{|c|}{ Marijuana } & Cocaine & Crack & \multicolumn{2}{|c|}{ Other PASs ${ }^{4}$} \\
\hline & \multicolumn{3}{|c|}{ Ex-user: 1,8} & \multicolumn{2}{|c|}{$2,3,5$} & \multicolumn{2}{|c|}{5,11} & 7 & 8,9 & \multicolumn{2}{|c|}{$7,8,9,11$} \\
\hline & \multicolumn{3}{|c|}{ Current: 2, 3, 4, 5, 6, 7, 11} & \multicolumn{2}{|c|}{$1,4,7,9,11$} & \multicolumn{2}{|c|}{$7,8,9,10$} & $8,9,10,11$ & 11 & & \\
\hline \multirow{2}{*}{ Orientation } & Time & \multicolumn{3}{|c|}{ Short-term memory } & \multicolumn{3}{|c|}{ Long-term memory } & Perception & \multicolumn{2}{|c|}{ Language } & Attention \\
\hline & & & & & & & & $7,10,11$ & & & $1,2,6$ \\
\hline \multirow{2}{*}{ Sensory functions } & \multicolumn{4}{|c|}{ Visual acuity } & \multicolumn{3}{|c|}{ Wear glasses } & & Hearin & $\mathrm{acu}$ & \\
\hline & $1,2,3$ & 4, 5, & $8,9,10$ & & & 3,4 & 6,11 & & & & \\
\hline Voctibulan osnots & Diz & ness/ & alance & & Vertig & & & Tinnitus & & $\mathrm{Nau}$ & \\
\hline vestivural aspects & & 1, 3, & & & 11 & & & $7,8,11$ & & 6 & \\
\hline
\end{tabular}

To be continued 
Chart 1 (concluded)

\begin{tabular}{|c|c|c|c|c|c|c|c|c|c|c|c|}
\hline Health/functioning systems & \multicolumn{11}{|c|}{$\begin{array}{l}\text { Alterations in health and functioning } \\
\text { Cases/Older adults with alterations }\end{array}$} \\
\hline \multirow[t]{2}{*}{ Use of medication } & SAH/Card & \multicolumn{2}{|c|}{ Analgesic } & DM & \multicolumn{2}{|c|}{$\begin{array}{l}\text { Cholesterol/ } \\
\text { Triglycerides }\end{array}$} & \multicolumn{2}{|c|}{$\begin{array}{l}\text { Anti-ulcer } \\
\text { agents }\end{array}$} & \multicolumn{2}{|c|}{$\begin{array}{l}\text { Psychiatric } \\
\text { medication }\end{array}$} & Others \\
\hline & $1,3,4,6,11$ & \multicolumn{2}{|c|}{$1,2,5,8,9$} & 3,6 & \multicolumn{2}{|c|}{3,4} & \multicolumn{2}{|c|}{6,8} & \multicolumn{2}{|c|}{$6,7,9,10,11$} & 11 \\
\hline \multirow{2}{*}{ Sleep/sleep functions } & Insomnia & \multicolumn{3}{|c|}{$\begin{array}{l}\text { Onset of/Difficulty to } \\
\text { sleep }\end{array}$} & \multicolumn{3}{|c|}{$\begin{array}{l}\text { Maintenance/wake up } \\
\text { more than } 2 \text { times }\end{array}$} & \multicolumn{3}{|c|}{$\begin{array}{l}\text { Quantity/less than } 7 \\
\text { hours of sleep }\end{array}$} & Siesta \\
\hline & 1,10 & \multicolumn{3}{|c|}{$1,6,9,10$} & \multicolumn{3}{|c|}{$1,6,9,10,11$} & \multicolumn{3}{|c|}{$5,9,10$} & $1,2,9,11$ \\
\hline \multirow{2}{*}{ Digestive system } & \multicolumn{4}{|c|}{ Food handling in the mouth } & \multicolumn{4}{|c|}{ Water intake below two litres } & \multicolumn{3}{|c|}{ Inadequate diet } \\
\hline & \multicolumn{4}{|c|}{7} & \multicolumn{4}{|c|}{$2,4,7,9,10$} & \multicolumn{3}{|c|}{$1,2,4,6,7,8,9,10,11$} \\
\hline \multirow{2}{*}{ Genitourinary functions } & \multicolumn{4}{|c|}{ Evacuation } & \multicolumn{3}{|c|}{ Urination } & \multicolumn{4}{|c|}{ Inactive sex life } \\
\hline & \multicolumn{4}{|c|}{ Liquid stool: 3 Constipation: 6} & & & & \multicolumn{4}{|c|}{$3,4,6$} \\
\hline \multirow{2}{*}{$\begin{array}{l}\text { Neuromusculoskeletal } \\
\text { functions }\end{array}$} & & bility & & & & Stal & ility & & & Tremo & \\
\hline & & & & & & & & & & 4,5, & \\
\hline Dain & Lower b & pain & & Thore & cic pai & & Join & pain & & Epig & stralgia \\
\hline & $1,3,5$ & & & & 2 & & $3,4,5$ & 6,11 & & & 7 \\
\hline Tolerance to physical & & & & & es not & erforr & physical act & jity & & & \\
\hline exercise & & & & & & & 4 & & & & \\
\hline Clein and nolator & Fingers & d nails & lo & & & Tin & ling & & & tiness and & allosity \\
\hline 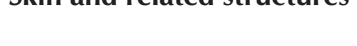 & & 2 & & & & $, 6,9$ & 10,11 & & & 8 & \\
\hline Activity and nanticination & Commu & y life & & creatio & al acti & ities & Daily routir & /Deci & ons & Cris & /Stress \\
\hline Activity antu partic ipationit & & & & &, 3 & & & & & 1,2 , & 10,11 \\
\hline Solf caro/locomotion & Change po & & & ansfere & רce & Wa & king/Moving & & & Self-car & \\
\hline - & & & & & & & & & & tting toena & : 3,9 \\
\hline Difficulties with climate/ & Wi & & & & isture & & & & & & eat \\
\hline temperature & & & & & 10 & & & & & & \\
\hline Fraoile sunnort networks & Family & & & Neig & abors & & lealth profess & onals & & & \\
\hline (1) & 8,11 & 8,1 & & 6,8 & 10,11 & & $2,5,8$, & & & $1,2,5,7$, & $9,10,11$ \\
\hline
\end{tabular}

Note: ${ }^{1}$ SAH: Systemic Arterial Hypertension; ${ }^{2}$ DM: Diabetes Mellitus; ${ }^{3}$ HIV: Human immunodeficiency virus; ${ }^{4}$ PAS: Psychoactive

\section{DISCUSSION}

The human body is formed by a communication network where everything is related, biological, chemical and physical interactions occur, with the parts and the whole. We are obligated to reduce from complex to simple since infancy, i.e., to separate what is connected; to decompose and not recover; and to eliminate everything that causes disorder or contradictions to our understanding, hindering the achievement of associations ${ }^{(4)}$.

Studying the physiological, psychological and social issues is necessary when dealing with the consumption PAS among older adults, aiming for the inseparability of the individual who appears as a triad, according to Morin ${ }^{(9)}$. The individual is located in the node of the biological instinct and the social order of culture interference, being considered the point of the hologram that contains the whole, conserving itself as unique ${ }^{(9)}$.

Health professionals/nurses need to be trained/enabled to use the ICF in the health assessment of older adults who consume PAS, in addition to considering ethics, objectivity and subjectivity through sensibility, criticism and the ability to handle the order and the disorder of the phenomena, reaffirming the complexity of its application.

Among the older adults in this research, biological alterations were identified. These might be influenced by the social order and accentuated due to the consumption of psychoactive substances such as alcohol, tobacco, marijuana and cocaine. 
During the process of aging, the older adult tends to develop Systemic Arterial Hypertension (SAH). Thus, the older adult who presents risk factors for hypertension, dyslipidemia, diabetes mellitus and physical inactivity are the most affected by the harmful effects of the use of PAS, since the consumption is related to the aggravation of various diseases that become more significant with the advance of age ${ }^{(10)}$.

Consumption of crack/cocaine and alcohol can increase arterial pressure and cause tachycardia, arrhythmias, ischemia and acute myocardial infarction. Chronic manifestations such as cardiovascular diseases can cause alterations of difficult future correlation to prior consumption ${ }^{(11)}$.

The older adults of this study use the substances from the infant stage, starting with the licit substances, due to easy access, to family influence and to the low cost, starting the illicit substances when adolescents or adults. The subjective and social needs of each individual are presented to the start of the consumption of substances; Drugs do not make the humans, but humans make the drugs, due to the obstacles/barriers of their stories. It should be noted that some find in the substance possibilities of life/trouble forgetfulness.

Epidemiological studies indicate that most individuals start to make use of psychoactive substances in adolescence and that the use has been increasingly intense and precocious. Defiance and curiosity are natural feelings of the youth, when they join a group that makes use of alcohol and other drugs they are attracted to try those too. They want to feel as equals, share experiences and solve their difficulties. Such results are similar to those found in this research ${ }^{(12)}$.

In our study, older adults who present depressive symptoms referred to difficulties in dealing with psychological and stress crisis, requiring the use of antidepressants or psychological help. Some older adults who consume PAS can present psychiatric comorbidities, the most reported are: psychotic delusions and hallucinations; depressive and anxiety disorders; and dementia ${ }^{(1)}$.

Concentration and memory problems are frequent among marijuana users. The psychological effects vary: they include relaxation, decreased anxiety, alteration in the temporal and spatial perception, experiences of depersonalization and derealization, in addition to self-referring ideas and hallucinations. Marijuana might contribute to the worsening of preexisting psychotic conditions, in addition to being a risk factor for triggering schizophrenia in susceptible individuals ${ }^{(11)}$.

In our research, three older adults users of illicit substances refer to alterations in perception, characterized by auditory and visual hallucinations. However, they report that when they use marijuana, such symptoms are not presented. Due to the serenity that this substance provides they often use it to decrease anxiety levels and to relax - for example, after a long day of work.

Regarding sleep/rest, sleep is considered a fundamental human need, which, however, is perturbed in the elderly person. More than $50 \%$ of the older adults living at home and $70 \%$ of the institutionalized present changes in the amount and quality of sleep, causing a negative impact on quality of life. Poor sleep quality results in difficulty to maintain attention; losses of memory, concentration and performance; and increased incidence of pain. Sleep problems might be the cause as well as the effects of illnesses ${ }^{(13)}$.

Regarding nutrition/hydration, the aging process causes alterations in the regulation and the stimulus of thirst, limiting the intake of liquids by the older adult ${ }^{(14)}$. Therefore, the fact that most of the older adults who participated of the study ingest less liquids than the minimum amount of two liters draws attention. In this age group the risk for dehydration is higher due to the sharp reduction in glomerular filtration rate.

These difficulties regarding nutrition and sleep/rest can be accentuated by the use of some PAS. The psychological effects of nicotine are the result of a mixture of stimulant and depressant effects. Increased concentration and attention; reduced appetite; anxiety; and insomnia are observed. Crack, among its effects, has the inhibition of appetite and sleep due to being a stimulant substance. These situations can lead older adults to malnutrition, dehydration and gastritis, causing a considerable loss of weight and physical debility ${ }^{(11)}$.

Marijuana presents the ability to stimulate the appetite and sleep, easing the crave for crack and decreasing the desire to consume alcohol ${ }^{(11)}$. There are reports of older adults who use marijuana and eat too much, and others who use cocaine and present insomnia and loss of appetite.

The aging process can be accompanied by chronic conditions, often followed by pain and high levels of physical dependence. Chronic pain is characterized by disorders that stretch for months/ years, in many of these situations this is the main complaint and cause of functional limitations. Research conducted with older adults in the state São Paulo identified that 377 (29.7\%) of them had some kind of chronic pain, being more frequent in the lumbar region and lower and upper limbs ${ }^{(15)}$; the results of location of pain are similar to those of the older adults of this research.

One of the main causes of low back pain is degenerative arthritis or osteoarthritis of the spine, which develops over time. Frequent falls, inflexibility, difficulty to walk, numbness, tingling, hot or cold sensations in the legs might happen. At first, the symptoms might be intermittent, but over time they might become more constant pain in the lumbar region ${ }^{(15)}$.

Morphological and physiological alterations in the ocular structure might appear initially between 40 and 50 years of age, generating the first ophthalmological symptoms ${ }^{(16)}$. Among the research participants, 10 older adults present decreased visual acuity and six use glasses.

As a result of aging, there are anatomical/physiological alterations in the vestibular system. Degeneration of the vestibulo-ocular reflex, the lack of balance when there is rotation of the body, episodes of dizziness and vertigo are the main alterations ${ }^{(16)}$. These symptoms might be accentuated when used by older adults: as an example, initially, the use of alcohol causes euphoria, disinhibition and imbalance; long-term, its use causes depressant effects, such as the lack of motor coordination $^{(10)}$, which can lead to falls.

Feelings of satisfaction/conformity were identified regarding the reports of health by the older adults who use PAS. Although the biological factors are extremely important to a good evaluation of the quality of life, the uniqueness of each assessment is perceived. The subjectivity in the selection of aspects that make 
life/health more enjoyable is different for each subject. The socioeconomic conditions have remarkable importance in studies on self-reporting of health and have the capacity to influence the understanding of the health state of the individuals ${ }^{(17)}$, conclusion corroborated by this research, in which the older adults consider themselves satisfied with their health/life for presenting conditions to economically supply their basic needs.

The older adults of the research present fragile links with the health professionals of the Basic Health Units of the neighborhood and only seek care for a symptomatic illness that are unrelated to the use of PAS. The older adult who is in treatment for withdrawal/reduction of drug consumption attends only the CAPS - AD, and there is no territorial monitoring.

Another study has already presented this same result, concluding that there is a great distance between users of PAS and health services. Despite most of the respondents claiming to refer to the UBS, this resource does not seem to be used to treat problems related to drug use, being used mostly for acute diseases ${ }^{(18)}$.

One factor that seems to distance the users of PASs from the health services is the lack of professional skills to handle these patients, who often suffer a social stigma and discrimination ${ }^{(18)}$.

Difficulty in identifying signs/symptoms of an older adult who consumes drugs can arise from many factors, such as: lack of technical skills of health professionals due to a mystification of the aging process or even a stereotyped image that drug consumption affects only the youth; or even shame, fear, lifestyle and the social isolation in which many older adults find themselves ${ }^{(2)}$.

Drug use is part of the history of mankind; however, care strategies vary in different cultures and historical moments. A situation of great transformations can be verified, discoveries of new knowledge and interactions with reality, with globalization, with the ecosystem, and also with the phenomenon of drugs ${ }^{(5)}$.

Modernity brings new changes and new paradigms and new postures when facing this phenomenon, which allows the introduction of the older adults who use PAS in society, through more flexible/diverse/complex views, embracing new ways of thinking. Considering the possibility of an older adult also being a user of PAS is to move away from common sense and dealing with uncertainty and multiplicity.

Intrinsic to the systemic paradigm, the recognition of the doubt and of the provisional conclusions might seem a factor that makes it difficult to use PAS. However, it is exact circumstantiality that creates a continuous learning process about the use of PAS among older adults and encourages the reflection, including complexity as way of thinking strategies/actions, and not only investigating the older adults.

The health conditions of the older adults need to be linked to cultural, social, economic, political and moral issues, being relevant to understand the environment in which the older adults live or transit, with a focus on the characteristics of their daily lives. This finding is consistent with the complexity thinking, for we need to study the dimensions of reality, simultaneously understanding their interactions, since the principle of separation harms and distorts the relation between the part and the context ${ }^{(4)}$.

Highlighting the concepts of order, disorder and uncertainty, addressed by Morin, becomes possible ${ }^{(19)}$. The randomness and disorder substitute the causality and the unidimensionality for a multidimensional thought. The order relates to stability, regularity and repetition ${ }^{(19)}$.

Moved by the scientific rationality that values order, health professionals/nurses sometimes understand that the patients belong to them, that they can decide their health condition by ordering healthy practices. However, this usually fails with those who consume PAS, due to the lack of linearity of their behavior.

Morin's recursion is the principle used to propose health/ nursing care to this population ${ }^{(4)}$. The recursion refers to the movement of going through it again happening many times, an unending movement of back and forth actions and implementations, these effects are at the same time causes and producers of the process itself. The nurse needs to know to handle the relapses of the older adults, working in a relational dynamic of dialogue and negotiation to avoid recursion.

Uncertainty is one of the guiding principles of humanity, through the use of complexity the comprehension of the contradiction and the unpredictable is proposed, through the integration of contradicting elements. Thinking using complexity means facing confusion, uncertainty and contradiction, without ignoring life with the solidarity of the existing phenomena ${ }^{(19)}$.

As for the participation in community/socialization of the older adults who use PAS, we can perceive a group of people who maintain independent lives, which provides them with well-being and motivation to move on. They exercise, they cycle and jog. They apply knowledge, they make decisions about their life and perform daily life activities. They travel by car, by bus or on foot, both in short or long distances.

Older adults who consume PAS are guided by a self-regulation mechanism that permanently recreates itself. Along with the older adult who uses PAS it is necessary that health professionals/nurses migrate to a permanent learning project, that they practice the dynamics of re-creation and that they seek to meet the wide range of health conditions in various levels of complexity and vulnerability. Using the complexity of Morin to assess the health/functioning of older adults who use psychoactive substances, exceeds the accuracy limits, to risk the understanding of the phenomena in its complexity.

\section{Study limitations}

The limitations of the study are related to the lack of research that approached the older adult who uses PAS through complexity or the ICF, which hinders the dialogue between different authors and the comparison of similar studies. The use of the Edgar Morin's theory of complexity as the reference created the need for more discussions about this topic, due to the change of profile and behaviors that the older Brazilian population has been showing and that they need to be comprehended by society and health professionals/nursing.

\section{Most relevant contribution to the field of Nursing, health, or public policies}

The most relevant contribution of our research to nursing, health, or public policies relates to the applicability of the instrument (based on the ICF), which allowed the observation/evaluation of the older adult in a comprehensive way, not just as a consumer of PAS; this will certainly ease the reflection of the nurse 
who has a professional attitude that gets closer to the assumptions of the theory of complexity. This study starts a discussion on the need of the nurse to welcome the older adults who consume PAS without judgment, their demands and needs, considering their uniqueness; it also stimulates the formation of a critic professional and an agent of change, who discusses the individual liberty to consume the substance and its possible consequences for the biological and social body, approaching Morin's assumptions.

\section{FINAL CONSIDERATIONS}

Our study reached the proposed objective to assess the health/functioning of the older adult who consumes psychoactive substances, through the International Classification of
Functioning, Disability and Health, to identify older adults who consider themselves healthy and who present the expected diseases of the aging process, which can be exacerbated by the use of PAS and by the social/cultural context subjectively experienced.

To nurses who perform their job with older adults who use PAS, it is suggested that they reflect on the nursing care for these patients; sailing from theory to practice and from practice to theory; and that consider issues such as solidarity, respect, uncertainty and the need for interdisciplinarity. We propose these new questions for future research: does ICF, in fact, contributes to the nursing care of older adults? Does the theory of complexity helps the nurse in the perception of the necessary demands of the older adult who uses PAS?

\section{REFERENCES}

1. Crome I, Dar K, Jankiewicz S, Rao T, Tarbuck A. Our Invisible Addicts. First Report of the Older Persons' Substance Misuse Working Group of the Royal College of Psychiatrists [Internet]. London: The Royal College of Psychiatrists. 2016 [cited 2016 Jun 14]. Available from: http://www.rcpsych.ac.uk/files/pdfversion/CR165.pdf

2. Pillon SC, Cardoso L, Pereira GAM, Mello E. Perfil dos idosos atendidos em um centro de atenção psicossocial: álcool e outras drogas. Esc Anna Nery Rev Enferm [Internet]. 2010 [cited 2016 Jun 14];14(4):742-8. Available from: http://www.scielo.br/pdf/ean/ v14n4/v14n4a13.pdf

3. Mesquita PFBA. Disposições para um novo envelhecimento: reflexões sobre ser velho na contemporaneidade. Geriatr Gerontol [Internet]. 2011 [cited 2016 Aug 12];5(1):46-51. Available from: http://sbgg.org.br/wp-content/uploads/2014/10/2011-1.pdf

4. Morin E. Da necessidade de um pensamento complexo. In: Martins EM. Para navegar no século XXI. Porto Alegre (POA): Sulina, Edipucrs, 2000.

5. MacRae E. Aspectos socioculturais do uso de drogas e políticas de redução de danos. Núcleo de Estudos Interdisciplinares sobre Psicoativos [Internet]. 2010 [cited 2016 Aug 12]. Available from: http://www.neip.info/downloads/edward2.pdf

6. Brasileiro IC, Moreira TMM, Buchalla CM. Classificação Internacional de Funcionalidade: incapacidade e saúde e seu uso no Brasil. Acta Fisiátr [Internet]. 2013 [cited 2016 Aug 12];20(1):37-41. Available from: http://www.scielo.br/pdf/rbepid/v8n2/11.pdf

7. Yin RK. Estudo de caso: planejamento e métodos. 3 ed. Porto Alegre (POA): Bookman, 2011.

8. Britten N. Entrevistas qualitativas na pesquisa em atenção à saúde. In: Pope C, Mays N. Pesquisa qualitativa na atenção à saúde. 3. ed. Porto Alegre: Artmed, 2009, p. 23-31.

9. Morin E. O método 5: a humanidade da humanidade. 5 ed. Porto Alegre (POA): Sulina, 2012.

10. Oliveira LC, Mascarenhas CHM, Melo NSA. Qualidade de vida e independência funcional de usuários de drogas atendidos em um Centro de Atenção Psicossocial Álcool e Drogas (CAPSad). Rev Bras Qual Vida [Internet]. 2014 [cited 2016 Aug 12];6(4):23240. Available from: https://revistas.utfpr.edu.br/rbqv/article/view/2019/1939

11. Chaim CH, Bandeira KBP, Andrade AG. Fisiopatologia da dependência química. Rev Med (São Paulo) [Internet]. 2015 [cited 2016 Aug 12];94(4):256-62. Available from: http://www.periodicos.usp.br/revistadc/article/view/108771/107197

12. Santos MA, Pratta EMM. Adolescência e uso de drogas à luz da psicanálise: sofrimento e êxtase na passagem. Tempo Psicanal [Internet]. 2012 [cited 2017 Feb 23];44(1):167-82. Available from: http://pepsic.bvsalud.org/scielo. php?script $=$ sci_arttext \&pid $=$ S0101-48382012000100010\&lng = pt

13. Bezerra C, Wilker J, Freitas MC, Galiza FT, Almeida PC. Sleep and rest needs of seniors: a study grounded in the work of Henderson. Acta Paul Enferm [Internet]. 2012 [cited 2016 Apr 4];25(1):54-9. Available from: http://www.scielo.br/pdf/ape/v25nspe1/09.pdf

14. Pereira SRM. Fisiologia do envelhecimento. In: Freitas EV, (Org.). Tratado de geriatria e gerontologia. 3 ed. Rio de Janeiro (RJ): Guanabara Koogan, 2011.

15. Dellaroza MSG, Pimenta CAM, Duarte YA, Lebrão ML. Dor crônica em idosos residentes em São Paulo, Brasil: prevalência, características e associação com capacidade funcional e mobilidade (Estudo SABE). Cad Saúde Pública [Internet]. 2013 [cited 2016 Apr 4];29(2):325-34. Available from: http://www.scielo.br/pdf/csp/v29n2/19.pdf

16. Esquenazi D, Silva SRB, Guimarães MAM. Aspectos fisiopatológicos do envelhecimento humano e quedas em idosos. Rev HUPE [Internet]. 2014 [cited 2016 Apr 4];13(2):11-20. Available from: http://revista.hupe.uerj.br/detalhe_artigo.asp?id=467

17. Confortin SC, Giehl MWC, Antes DL, Schneider IJC, d'Orsi E. Autopercepção positiva de saúde em idosos: estudo populacional 
no Sul do Brasil. Cad Saúde Pública [Internet]. 2015 [cited 2016 Apr 4];31(5):1049-60. Available from: http://www.scielo.br/pdf/ csp/v31n5/0102-311X-csp-31-5-1049.pdf

18. Cruz VD, Campos RZ, Silva PM, Al Alan MCL, Goulart GL, Oliveira MM. Rede de apoio social dos usuários de crack em PelotasRS. J Nurs Health [Internet]. 2012 [cited 2016 Apr 4];2(Suppl):S127-40. Available from: https://periodicos.ufpel.edu.br/ojs2/ index.php/enfermagem/article/view/3492

19. Morin E. Introdução ao pensamento complexo. 5 ed. Lisboa: Instituto Piaget, 2008. 